\title{
CONFESSAR SIM, MAS NEM TUDO: O DISCURSO INACIANO SOBRE A CONFISSÃO NAS REDUÇÕES JESUÍTICAS
}

\author{
GUILHERME GALHEGOS FELIPPE ${ }^{1}$
}

PUCRS

\begin{abstract}
RESUMO: As reduções jesuíticas do Paraguai caracterizaram-se por estabelecer um local de convívio direto e contínuo entre o cristianismo e os nativos. Os padres buscavam orientar diariamente os índios à vida cristã através de missas, sermões, ensinamentos e sacramentos. A confissão sacramental, acima de todos os outros, tinha uma papel fundamental na medida em que servia não apenas como uma forma de os pecadores redimirem-se, mas também era a maneira dos padres manterem-se informados a respeito do andamento da evangelização no meio reducional: acreditavam que quanto mais confissões eram realizadas, mais difundida estaria a religião cristã na vida nativa. O presente artigo procura analisar como se deu a assimilação do sacramento pelos índios e como o discurso inaciano ajusta-se às dificuldades surgidas.
\end{abstract}

PALAVRAS-CHAVE: Reduções jesuíticas; Confissão sacramental; Século XVII.

ABSTRACT: The Jesuitic reductions in Paraguay were characterized for establishing a place of direct and continuous contact between Christianity and the natives. The priests seeked to offer Indians guidance on an everyday basis to the Christian life through masses, preaching, teaching and sacraments. Sacramental confession, above all else, had a fundamental role since it served not only as a way of redemption to the sinners, but also as a way for priests to keep themselves informed about the progress of evangelization in the reductional environment: they believed that the more confessions that were performed, the more widespread would Christian religion be in native life. The present article will analyze how the assimilation of the sacrament came to be among the Indians and how Ignatian discourse adapts itself to the difficulties that arise.

KEYWORDS: Jesuitic reductions; Sacramental confession; XVII century.

Quando se lançaram à empresa reducional paraguaia, os jesuítas procuravam estabelecer uma relação mais estável e duradoura para com os índios, e isto resultou na tentativa de doutriná-los através do cotidiano pautado em ensinamentos e práticas cristãs. $O$ batismo, bem

\footnotetext{
${ }^{1}$ Possui graduação em Licenciatura em História pela Pontifícia Universidade Católica do Rio Grande do Sul (2004) e mestrado em História pela Pontifícia Universidade Católica do Rio Grande do Sul (2007). E-mail: cpantagruel@yahoo.com.br.
}

Espaço Ameríndio, Porto Alegre, v. 2, n. 2, p. 124-150, jul./dez. 2008. 
como as missas e a educação infantil, foram os principais meios de vincular à vida nativa a religião católica. Batizados, os índios passariam a uma nova etapa em sua vida reducional: seriam cristãos e deveriam agir como tal. Desta forma, o novo fiel passa a assumir algumas responsabilidades, como a realização de rituais e a participação em cerimônias, cuja função é propiciar uma rotina sempre ligada à religião. Junto a isso, a pedagogia cristã opera no imaginário do fiel, com a função de motivá-lo a aderir à fé, explorando

as emoções, como o medo e a angústia, integra-as à problemática do pecado e da danação, dissipa-as por meio de técnicas rituais, como a confissão e a penitência, conduzindo à plena assimilação da temática cristã da salvação e da redenção (GRUZINSKI , 2003, p. 288).

É nesta forma de atuação evangélica, em que o imaginário do fiel é estimulado a fazê-lo recorrer cada vez mais à ajuda sacerdotal, que a confissão sacramental vai ter função básica para regular a vida de seus crentes.

No Concílio de Trento, estabelecem-se modificações substanciais na maneira de promover a confissão, atribuindo-lhe maior importância como sacramento obrigatório:

Combatida pela Reforma Protestante que a julgava charlatanice - pois só Deus, pregavam os reformadores, tinha o poder de salvar ou condenar -, a confissão sacramental foi peça-chave na estratégia da Contra-Reforma: valorizada enquanto sacramento e renovada em sua técnica. O moderno confessionário, separando confessor e penitente por meio de telas ou grades, e posto à vista do público no interior das igrejas, foi uma das invenções do Concílio de Trento, abolindo-se as confissões privadas e íntimas que, aproximando sacerdotes e filhas (ou filhos) espirituais, mais incitavam que coibiam os pecados da carne (VAINFAS, 1997, p. 24).

A importância do sacramento está justamente em seu caráter manipulador: expondo seus pecados, o fiel admite ter cometido erros, arrepende-se e confia-os ao padre. Desta forma, a Igreja passa a policiar as ações e pensamentos de seus crentes, impondo-Ihes limites 
GUILHERME GALHEGOS FELIPPE - Confessar sim, mas nem tudo ...

e condutas que devem ser seguidos. Neste contexto em que o catolicismo rege as condutas morais, "o confessor tornou-se um personagem insubstituível" (DELUMEAU, 2003, p. 13/ v. 1), responsável por ouvir os pecadores, analisar seus erros e atribuir-lhes punições a fim de se redimirem. Porém, para que o sacramento tivesse total eficácia, o indivíduo deveria confessar "perfeita e verdadeiramente todos os pecados, sem exceção", com sentimentos de dor e pesar, odiando seus erros e com o propósito de nunca mais cometê-los (VAINFAS, 1997, p. 44). Caso algum pecado fosse omitido por "vergonha, por temor, por uma negligência estudada ou por falta de exame cometeria um sacrilégio que tornaria sua confissão nula e que o obrigaria a repetila" (DELUMEAU, 2003, p. 266/ v. 2). Por isso, além de ser uma forma de redimir o pecador pelas suas falhas cometidas, era um mecanismo bastante útil para examinar a mente dos fiéis, fazendo do confessor um "especialista de casos de consciência" (DELUMEAU, 2003, p. 399/ v. 1).

Nas reduções não foi diferente. Os jesuítas, em sua empresa evangelizadora, davam grande atenção ao sacramento. Nota-se isto pela grande quantidade de vezes que relatos envolvendo confissões indígenas são registrados nas correspondências jesuíticas. Os padres conheciam bem a dificuldade que era converter os índios e, ainda mais, mantê-los nesta nova vida religiosa ${ }^{2}$. Desta forma, a confissão tinha papel fundamental, na medida em que servia como um instrumento para policiar as atitudes dos novos fiéis e fazê-los pagar pelos seus pecados por intermédio das penitências.

A intenção aqui é justamente tentar saber se houve esta introspecção da nova religião observando os casos de confissão. Para isso, será feita a análise das diversas formas que o sacramento é acionado no discurso inaciano, partindo-se de casos aparentemente edificantes - como, por exemplo, registros de inúmeras confissões realizadas em um curto período de tempo, índios confessando pecados minuciosamente com mostras de emoção e confissões no momento da morte. Depois, será discutida a falta do registro de pós-confissão destes casos modelares, contrapondo-os justamente a relatos que evidenciam o comportamento posterior do recém-confesso. Com isto, será constatado que um grande problema do discurso confessional

\footnotetext{
${ }^{2}$ Cf. Felippe (2007).
} 
jesuítico é a pouca relevância dada ao destino comportamental do índio que acabou de confessar seus pecados, em oposição ao grande destaque dado nos registros ao ato confessional em si. Para tentar compreender como se formou este modelo de discurso, serão analisados os casos extraordinários, cujo enfoque privilegia as situações que motivavam os índios a se confessarem, e os relatos envolvendo más confissões.

\section{A confissão como discurso edificante}

Alguns relatos provenientes das correspondências jesuíticas evidenciam a importância depositada no ato confessional, existindo registros que enaltecem a realização de um grande número de confissões praticadas em uma única redução, como afirma o padre Pedro Romero ao contabilizar 700 confissões realizadas no ano de 1634, todas com mostras de bastante emoção dos índios, que o fizeram "derramando muitas lágrimas de dor e arrependimento" (MCA, 1969, p. 45).

O autor busca enaltecer o bom andamento da empresa evangelizadora, apresentando um número de confissões realizadas bastante alto, comprovando a sua boa aceitação entre os índios, além de ressaltar a emoção com que se confessaram. Este vai ser um recurso bastante comum nestes relatos, onde muitos jesuítas vão procurar descrever os sentimentos aflorados pelos índios no momento de sua confissão, agregando ao sacramento uma importância moral, tendo em vista a suposta necessidade com que os indígenas procuram confessarse. Pode-se perceber esta relevância dada à emoção em um relato do padre Nicolau Duran de 1628:

Passam de ordinário de mil e quinhentos, havendo-se exercitado antes em outros atos de devoção e preparando-se com confissões gerais que, para chegar com mais pureza, fazem com tanta luz da gravidade do pecado que ocorre de se acusarem com muito sentimento dos cometidos em sua infidelidade (MCA, 1951, p. 221). 
O inaciano, além de enfocar a grande quantidade de índios que realizaram a confissão, tenta descrever a emoção destes ao praticá-la. Para reforçar e dar consistência a estes sentimentos indígenas surgidos na hora do ato confessional, o autor afirma que os confessos também confiaram aos padres seus pecados cometidos "em sua infidelidade", ou seja, a confissão de "pecados" praticados antes da existência da religião cristã na vida indígena. $O$ padre Pedro Romero também registra algo semelhante ao citar o que os índios Ihe falam: "Padre, agora parece que abri os olhos e entendi que coisa é a confissão e assim mesmo quero corrigir os erros passados que sem dúvida cometi quando não sabia" (MCA, 1969, p. 43). Os índios passam a recordar de "pecados" cometidos antes mesmo de conhecerem a nova crença trazida pelos estrangeiros - tema que será abordado adiante. Por hora, não se discutirá a visão que os indígenas tinham de pecado ou erros morais, mas cabe observar estes trechos citados como uma forma de criar um discurso otimista a respeito da introdução do sacramento da confissão aos nativos, visto que, de acordo com o que os autores registram, os índios passam a perceber falhas em seu comportamento dignas de uma confissão cristã e chegam a atitudes extremas, como foi registrado em 1642 o caso de um menino que pedia, em suas orações, para que Deus "conservasse magro e sem forças seu corpo para lhe ter mais obediente e não ser vencido pelo demônio em pecados desonestos" (MCA-CPH, cx. 29, doc. 7).

Em outro relato de uma carta de 1635, o padre Pedro Romero novamente salienta as emoções reveladas na hora da confissão: "Comparecem quase todos os dias muitos índios e índias a confessar-se fazendo com dor de seus pecados e com muita confiança neste santo sacramento" (MCA, 1970, p. 91). Da mesma forma descreve o padre Martin Xavier em uma curta carta em que relata sua entrada na região do Guairá onde permaneceu 15 dias por insistência dos nativos, orientando e confessando um a um, dizendo-lhes "o que Ihes concernia fazer e as obrigações que tinham" (MCA-CPH, cx. 14, doc. 12).

Fica evidente a intenção do padre em edificar um caso envolvendo o sacramento e promover o trabalho jesuítico mostrando a paciência, devoção e preocupação dirigidas aos indígenas. Da mesma forma, os 
GUILHERME GALHEGOS FELIPPE - Confessar sim, mas nem tudo ...

padres também procuram salientar as boas confissões praticadas pelos índios, como em um relato de 1637:

Um índio que em seu modo parecia-me muito boçal, estando doente, confessou-se com tanto cuidado de todos os seus pecados, grandes e pequenos, que, admirado da confissão, disse no fim: "é verdade que não entra ninguém no céu com uma mínima mancha" (MCA, 1970, p. 153).

O enfoque dado pelo autor do relato é a realização de uma boa confissão, ou seja, a revelação de todo e qualquer tipo de pecado cometido pelo índio, desde os maiores erros até os menores deslizes praticados, ainda que o confesso não transparecesse, ao padre, tal capacidade. Conseguir fazer com que os indígenas confiassem todos seus íntimos segredos ao confessor era o principal objetivo dos jesuítas, no que tange à questão da confissão sacramental. Em um trecho escrito pelo padre Nicolau Duran também se percebe esta exaltação da boa confissão praticada: "El hábito de la confesión lo observan con regularidad y es tal la ternura de estas puras criaturas que, por la más ligera falta, en los ojos les afloran abundantes lágrimas" (DUVIOLS, 1991, p. 101). Mesmo confiando pequenas falhas aos padres, os indígenas, segundo o jesuíta, emocionam-se com o ato confessional, praticando-o de forma correta. Pode-se imaginar como este tipo de relato repercutia de forma satisfatória aos demais sacerdotes que, sabendo da boa adesão dos índios ao sacramento, sentiam-se encorajados e motivados a permanecer com o trabalho evangélico. Registros como estes tinham uma função importante não só para informar como andava a empresa reducional, mas também para alertar os demais padres das dificuldades enfrentadas e das facilidades conquistadas, como a boa aceitação dos índios à confissão sacramental. De acordo com os relatos, o sacramento da confissão foi tão bem introduzido na vida reducional que os índios "têm-no tão acreditado que, vendo-se em qualquer necessidade ou perigo, amparam-se nele como remédio geral de todos" (MCA, 1951, p. 223), chegando, algumas vezes, a pedirem a confissão, segundo os jesuítas, pensando em uma boa morte (MCA-CPH, cx. 29, doc. 5). 
São bastante comuns casos onde o indígena morre logo após realizar sua confissão, criando um grupo bastante expressivo de relatos na documentação. Os casos que serão chamados aqui de confissão seguida de morte são registrados como situações edificantes à evangelização. $O$ fato é que a realização do sacramento confessional no leito de morte não é só esperada como necessária para a boa morte do indígena, tendo uma função reconciliatória entre o moribundo e a cristandade. Nestes relatos, muitas vezes, o óbito ocorre instantes depois da confissão:

Têm morrido alguns por picadas de cobras. Um era já cristão e, ainda que o mordeu duas vezes e era muito venenosa, contudo quis se confessar até que chegou o veneno ao coração e logo morreu (MCA-CPH, cx. 28, doc. 11).

Sua morte eminente acelera o processo e leva o índio a realizar a confissão, aparentemente sem qualquer preparo para isto. $O$ enfoque dado pelo autor do trecho supracitado está no ato sacramental em si e no fato de ter ocorrido uma boa morte do recém-confesso, dando ao relato um final edificante. Os casos de confissão seguida de morte vão apresentar estas características, sempre ressaltando o ato confessional e a importância de ser realizado no leito de morte dos índios. Em alguns casos, o foco também é dado ao esforço realizado pelos jesuítas e sua dedicação aos nativos, como se percebe em um registro de 1613 do padre Roque González:

O outro foi um índio que, na visita de Don Francisco, veio para cá com sua mulher e saindo um dia para caçar com outros índios desta redução, que costumam fazer freqüentemente cinco ou seis léguas daqui, picou-lhe uma cobra que não o deixou mexer-se do lugar. Seus companheiros vendo-o assim e vendo que não teriam como Ihe trazer, nem poderiam chegar com ele nesta redução, determinaram-se de deixar ele no monte e vir avisar-nos para que fôssemos vê-lo e confessá-lo. Fizeram assim, ainda que não deram a pressa que deviam, porque não avisaram depois de dois ou três dias que Ihe havia picado a cobra. Eu parti logo com toda a pressa que pude, ainda que desavisado de achar-lhe vivo, porque seus companheiros diziam que a cobra que the havia picado 
era muito má e que ele estava muito cansado e que ali aonde the haviam deixado havia muitos tigres e que por ventura algum o havia comido. Eu, contudo, determinei-me de ir vê-lo ainda que com o temor de não achá-lo vivo. Chegando perto do lugar onde lhe havia deixado, dobrou-se minha pena e temor, porque vi naquele lugar muitos corvos que pensei que haviam comido o corpo morto. Cheguei e achei-o estendido nu no solo e cheio de cinzas, porque com as ânsias da dor havia revirado-se em um pouco de fogo que haviam deixado seus companheiros; tinha a boca e o nariz repletos de terra e cinzas. Vi que não se mexia e chamando-o não me respondia. Tive-o por morto ainda que o coração dizia-me que não estava. Fiz buscarem um pouco de água e enquanto isso fui limpando a boca e o nariz, lavei-Ihe os olhos que estavam fechados com sangue que, pela força do veneno, havia saído por eles; lavei-lhe a boca que a tinha muito seca. Parecia que me olhava e que ofegava tanto quanto eu. Com isto, comecei a chamar-lhe a atenção. Começou a recobrar a respiração e assim abriu os olhos e conhecendo-me animou-se de sorte que não parece senão que tenha visto um anjo do céu. Disse-me que queria confessar e o fez muito bem e acabando de dar a absolvição deu sua alma ao Senhor (MCA-CPH, cx. 28, doc. 8).

Este longo relato sobre a confissão de um índio mortalmente ferido por uma cobra evidencia a importância dada à preocupação dos padres em confessar os nativos. Ao contrário da objetividade do relato anteriormente citado, este apresenta minuciosamente o que ocorreu quando o padre soube do acidente até a realização do sacramento e morte do índio. Inicia criticando a lentidão dos outros índios que demoraram dias para avisar do ferido na mata, mostrando a falta de confiança neles e depositando em si a responsabilidade de salvá-lo. O relato prossegue com sua aproximação a um corpo bastante desgastado e sujo que parecia ainda estar vivo apenas esperando sua chegada. Mostra-se muito preocupado e esperançoso e faz tudo o que pode para reanimar o índio e conseguir aplicar-lhe a confissão. No final do trecho, em poucas linhas, informa que o sacramento foi bem realizado e teve seu fim esperado. Após toda uma densa descrição, preocupada em apresentar o descaso dos demais indígenas, sua angústia e esforço canalizados para a situação do ferido e o trabalho que teve para 
reanimá-lo, Roque González finaliza o caso de forma satisfatória e eficaz. O sacramento é só mais um ponto dentro de todos os outros citados, ficando apenas como pano de fundo de todo o relato. Mesmo assim, ele segue a linha lógica deste tipo de caso: a confissão no momento da morte, que não é só esperada como necessária para o moribundo, e sua reconciliação com a religião.

Porém, analisando outros casos de confissão seguida de morte, pode-se observar peculiaridades do discurso jesuítico sobre a confissão, como a supervalorização do sacramento em razão da falta de práticas religiosas:

Um índio surdo e com mais de noventa anos estava em um rancho ou cabana de uma boa índia que de pura caridade o sustentava. Havia muitos anos que não se confessava por falta de ministros, e tendo notícias dele foi ver-lhe o padre Aranda e levou alguns presentes e achou nele uma alma admiravelmente disposta e desejosa de ver Deus. Confessou-o e deuIhe a extrema unção e logo outro dia morreu (DHA. 1927 , p. 8).

Diferente do caso anterior, aqui a confissão tem maior importância no relato, destacando-se desde o início do mesmo como algo inadiável para o idoso. É justamente neste ponto que se evidencia o lapso do discurso: um índio velho, que vivia longe dos padres, não é descrito como cristão ${ }^{3}$ e, segundo o autor, fazia tempo que não se confessava. Nestas condições, é questionável a sua inclinação à fé cristã e a utilidade da confissão em sua vida. Mesmo o sacramento tendo um maior destaque neste relato, torna-se inócua a sua realização. São dois casos que apresentam problemas discursivos distintos, cada um a sua maneira: se no relato anterior o sacramento da confissão não teve grande realce em detrimento de uma atitude exemplar do índio que

\footnotetext{
${ }^{3}$ Sabe-se que para a realização do sacramento confessional é necessário que o indivíduo seja batizado, e com os índios não era diferente. Porém, crê-se aqui que é muito significativa a falta desta informação à descrição do índio, ou seja, o autor busca adaptar o caso ao modelo de discurso edificante, entretanto, acaba por descrever atitudes e práticas do indígena que em nada correspondem a de um cristão. Obviamente, sua ausência pode ser justificada pelo simples esquecimento do autor, mas é difícil pensar que com tantas descrições sobre a vida do idoso, a mais importante tenha passado em branco. Apesar de não ser o único caso registrado sem especificar que o indígena era cristão, a falta aqui é maior devido à vida que o idoso levava longe do meio reducional e, por conseguinte, longe dos costumes, práticas e crenças cristãos. Não identificá-lo como já batizado - ou esquecer disto - debilita o próprio discurso jesuítico.
} 
esperou o confessor chegar para depois morrer, neste caso supracitado ocorre o inverso, onde o sacramento teve um foco expressivo, inversamente proporcional à dedicação à fé católica do nativo.

Em outro caso registrado pelo padre Roque González em uma ânua de 1619, depara-se com o exemplo de uma índia, identificada pelo autor como cristã, que vivia há 30 anos com índios infiéis, pois, desde criança, sua mãe havia levado-a a morar com eles. Ao adoecer, pediu para que a levassem aos padres. Somente depois de muito insistir, "a trouxeram em uma canoa persuadindo outros dez que viessem com ela; entre eles vinha seu mancebo". Quando o padre Roque González a viu, certificou-se que já era batizada e orientou-a a "confessar e que antes se separasse de sua má companhia". Ao fim, a índia "saiu da casa do índio e foi para outra onde se confessou com muitas mostras de fé e, acabando de confessar, morreu" (MCA-CPH, cX. 28, doc. 15).

Neste caso, torna-se mais evidente a fragilidade da confissão praticada pela índia. Após viver tanto tempo com indígenas infiéis, distante do contato com os jesuítas e vivendo com um índio, ela decide procurar os padres por estar doente. $\mathrm{O}$ autor do trecho informa que a índia fora levada ainda pequena por sua mãe para viver longe do convívio jesuítico, deixando entender que o seu batismo foi realizado quando ainda era uma criança. Quando o padre Roque González aceita aplicar-lhe a confissão, só impõe a condição de deixar seu mancebo sem dar a opção de casarem-se cristianamente. Após largá-lo, a índia realiza provavelmente a primeira confissão de sua vida, sem passar por ensinamentos, ter ouvido sermões ou comparecido a missas e, mesmo assim, sua confissão é muito bem-vista pelo autor que nunca questiona sua inclinação à fé. Parece que realmente "Deus observa menos os fatos do que as intenções" (DELUMEAU, 2003, p. 96/ v. 2). Além disso, o relato termina com a morte da índia, fazendo com que não se tenha certeza da eficácia da confissão: a sua boa morte dá um caráter edificante ao caso, mas deixa dúvidas quanto à utilidade do sacramento na vida da índia. Não se sabe se ela realmente tinha conhecimento do que estava fazendo, que tipo de "pecados" confessou, se iria mudar-se para a redução ou se, dali em diante, confessaria com mais freqüência. 
Mas, de acordo com o discurso jesuítico, sua morte aboliu as dúvidas e glorificou o sacramento.

O que se verifica são milhares de índios se confessando aos padres, emoções afloradas em forma de lágrimas, confissões minuciosas dos mais íntimos e pequenos erros, indígenas admitindo pecados de um passado pagão e confissões no leito de morte em registros otimistas quanto à boa aceitação nativa ao sacramento. Questiona-se, então, se a confissão sacramental foi incorporada aos costumes indígenas sem maiores problemas e se foi sempre realizada de forma satisfatória. Para responder a esta questão deve-se antes observar um ponto que foi ou ignorado ou omitido nos relatos até aqui citados: a questão da pós-confissão. Apesar de todo o otimismo presente nos registros, nenhum faz referência ao destino tomado pelo recém-confesso. Desta forma, são relatos satisfatórios e promovedores do sacramento, mas não o descrevem como sendo um ritual cristão eficaz, já que não se têm notícias do bom comportamento dos índios após a confissão.

Casos que, em seu desfecho, dão conta do comportamento do indígena após realizar o sacramento são uma minoria. Esta baixa quantidade de relatos é um dado expressivo, ainda mais se levando em conta a importância que esta informação acrescenta à credibilidade e eficácia dos registros. Torna-se relevante, pois, analisar casos em que o jesuíta registra alguma informação sobre o comportamento pósconfissão, para tentar entender de que forma eles são estruturados, com qual importância esta informação aparece no discurso e se existe algo sendo omitido ou salientado nos mesmos.

Em um caso registrado pelo padre Pedro Romero, um índio "com intensas dores que não lhe deixavam repousar há três meses", confessou-se e logo sarou, não voltando mais as dores e "assim levantou-se e pôde trabalhar" (MCA, 1970, p. 93).

Movido a confessar-se pelas intensas dores que sentia, o índio só melhorou fisicamente após realizar o sacramento, tornando o relato edificante. Um caso semelhante é registrado em uma carta de 1642 pelo padre Pedro Comenzalo:

Entre outros, um ouviu, em um domingo, um sermão em que Ihes foi contado um exemplo de uma pessoa 
que, ainda que o padre o tenha admoestado, não havia querido aproveitar e que no fim morreu mal e se condenou. O dito índio ouviu isto, espantou-se vendose como em um espelho, percebendo que ia pelos mesmos passos; por outro lado, via-se tão atado que Ihe parecia que não havia como deixar seu vício. DeuIhe um sentimento muito vivo dizendo: "a mim Deus enviava algum grande castigo, pois não saio de sua ofensa". Dito isso passaram três dias, que parece que o Senhor deu-lhe para que se confessasse e corrigisse. Não o fez e, assim, ao terceiro dia, vindo da chácara e sentando-se em sua rede para descansar, deu-lhe de repente uma terrível febre nunca vista que lhe pesou todo o corpo como chumbo e lhe atacou os nervos, a ponto de me chamar e dizer o que se passava. Confessou-se com muita dor e, conhecendo o castigo do Senhor, fez muitos propósitos e ao fim melhorou (MCA-CPH, cx. 29, doc. 6).

Apesar de o relato iniciar informando que o índio em questão havia se inclinado a confessar por ter presenciado um sermão que o tocou, foi seu estado físico que o levou realmente ao confessionário. 0 autor chega a citar que o indígena mantinha "vícios", porém não diz quais eram, não sendo eles os responsáveis pela realização do sacramento. Segundo o relato, era intenção do índio ir confessar-se depois que ouviu o exemplo de um indivíduo que foi castigado por não seguir os conselhos do padre. Percebendo que levava sua vida pelo mesmo caminho, como escreve Comenzalo, o índio promete ir à confissão, o que não cumpre. Nem os "vícios", nem o exemplo do homem castigado fazem com que realmente o indígena vá procurar o confessor. Somente quando cai doente, atingido por uma febre, é que o sacramento é realizado, e assim o relato finaliza com sua melhora.

Ambos os casos citados assemelham-se pela motivação que levou ao ato confessional. Nenhum dos autores responsabiliza algum pecado concreto que tenha incentivado o indígena a procurar sua reconciliação. $\mathrm{Na}$ verdade, a confissão, nestes dois casos, passa a ter outro caráter: o sacramento não foi procurado para limpar pecados cometidos, mas sim para curas físicas. Um verdadeiro remédio do corpo, e não da alma. Estes relatos que deveriam apresentar casos de confissão eficaz e modelar têm suas falhas: apesar de darem conta da pós-confissão, não tratam a questão do pecado que, teoricamente, deveria ser o motivo 
principal para que um indivíduo procurasse o confessor. Ao contrário, estes relatos parecem demonstrar que os indígenas utilizavam a confissão como uma forma de curar doenças, agregando outra função ao sacramento que não era a esperada pelos padres.

Mas esses são apenas dois casos dentre outros que, ainda que poucos, não devem ser ignorados. A diferença é que os demais estão dentro de um outro grupo de relatos envolvendo a confissão, que, devido a sua importância dentro dos registros confessionais, deve ser analisado à parte.

\section{Casos extraordinários ${ }^{4}$}

Pertencem a este grupo relatos que contêm situações fantásticas, intervenções sobrenaturais, como aparições, vozes, ruídos ou fenômenos incomuns, que levam à confissão indígena. Os casos extraordinários têm, na documentação, praticamente uma mesma incidência quantitativa do que os casos que tratam da pós-confissão. A diferença é que relatos que contêm informações sobre o indígena após confessar-se - seja a respeito da penitência ou de alguma mudança em seu caráter - são esperados no discurso jesuítico, ao contrário de casos fantásticos, ainda mais que culminem com confissão. Por isso a análise destes relatos é importante para tentar compreender qual motivação levava os índios, segundo os jesuítas, a procurarem o sacramento.

Um bom exemplo desses casos extraordinários é um registrado pelo padre Nicolau Duran, em 1628, sobre um indígena que, após morrer, devido uma grave doença, ressuscitou pedindo para falar com o padre. Após ter com ele, implorou para que o confessa-se novamente, já que em sua primeira confissão - realizada antes de sua morte -, havia ocultado culpas. Ainda contou ao jesuíta que, enquanto estava morto, veio-Ihe de encontro Jesus Cristo e a Virgem Maria, insistindo-Ihe que se confessasse bem. Com isso, conta o padre Duran, "confessou-se com

\footnotetext{
${ }^{4}$ Usa-se aqui a expressão casos extraordinários, tendo como influência o estudo de Carla Berto sobre os milagres acionados pelos jesuítas em seus registros na empresa reducional. A autora analisa casos relatados pelos padres em que indígenas teriam visto, ouvido ou se comunicado com aparições, sejam elas maléficas ou benéficas, concluindo que a "seleção e a interpretação do jesuíta constituem-se o fato decisivo de atribuição divina ou demoníaca a estes casos de aparições” (BERTO, 2006, p. 155).
} 
muita mostra de sentimento e pouco depois foi-se para a eterna" (MCA, 1951, p. 223).

O relato não trata apenas da ressuscitação do indígena - o que já seria bastante incomum -, mas também da visão divina que teve e que foi a responsável pela sua boa confissão. $O$ interessante é que o padre Duran deixa claro que o indígena havia já se confessado antes de morrer, porém ocultou coisas e por isso ressuscitou e voltou a realizar o sacramento. Mas a primeira confissão não é o foco do relato: ela só é citada para mostrar que havia sido feita com falhas, para então justificar a volta do morto. A importância do relato está na visão de Jesus e Maria que levou a uma segunda, e satisfatória, confissão. Mesmo assim, a finalização do caso não torna o sacramento eficaz, tendo em vista a morte, enfim, do recém-confesso.

Mas, como foi dito, alguns casos que dão conta da pós-confissão fazem parte dos casos extraordinários, como um registrado pelo padre Diogo de Boroa, em 1614:

A outra pessoa (segundo ela referiu) fez-lhe ver Nosso Senhor os fogos do inferno e depois teve outra admoestação divina, tudo, segundo entendo, entre sonhos, estando doente, ajudando-a também interiormente e pressionando-a o mesmo Senhor com que veio a fazer uma boa confissão e mudança (MCA, 1952, p. 18).

Neste relato objetivo sobre um provável sonho que a índia teve, o jesuíta deposita nos conselhos de Deus o motivo para que a boa confissão fosse realizada. Além disso, Diogo de Boroa concluiu que uma "mudança" foi provocada na recém-confessa, não especificando qual, porém sendo uma importante colocação se for levado em conta a escassez deste tipo de informação nos casos de confissão. Um caso extraordinário que termina com a eficaz atuação do sacramento, tal como relata Nicolau Duran:

Deu um tempo em comparecer a uma casa para aterrorizar seus moradores com balidos e grandes estrondos e rastros que deixavam pisadas de cabra e outros animais. Fugiram os daquela casa espantados com estas visões, mas depois, reparando em si, buscaram melhor remédio comparecendo todos a 
GUILHERME GALHEGOS FELIPPE - Confessar sim, mas nem tudo ...

confessar e desde aquele dia não se atreveu mais o demônio a inquietar-los (MCA, 1951, p. 223).

O que diferencia este caso do anterior é o tipo de atuação que levou os índios a se confessarem. Desta vez, bramidos de animais e marcas no solo espantaram os moradores da casa, fazendo com que, num primeiro momento, fugissem. Mas só depois, quando procuraram confessar-se, é que o problema foi realmente solucionado, fazendo do caso um relato edificante. Mesmo assim, como no trecho citado anteriormente, nenhum dos dois relatos dá conta de qualquer pecado que possa ter sido cometido pelos indígenas envolvidos. Na realidade, o que os levou à confissão foram situações inusitadas que, ao que parece, não têm relação alguma com pecados ou falhas morais, diferente do que se passa em um caso registrado pelo padre Pedro Romero em uma carta de 1635:

Um pobre índio, como homem fraco e miserável, caiu em um pecado e, logo à noite, o santo, como tão zeloso da honra de Deus, repreendeu-o e castigou-o. Apareceu-lhe entre sonhos, muito vistoso e resplandecente, embranquecido, e repreendeu-lhe asperamente pelo pecado que havia cometido e, ao fim, deu-lhe dois tapas que lhe servissem de lembrança. Acordou com isto o índio apavorado e logo pela manhã foi choroso confessar-se e contou ao padre o que the havia passado. Disse-lhe então o padre o que convinha fazer para não irritar mais a Santo Inácio e o índio fez muito bem e vive agora com mais cautela (MCA, 1970, p. 83-4).

O pecado passa a ter mais importância neste caso, sendo o responsável pela repreensão da Santo Inácio. Ainda assim, o que levou efetivamente o índio à confissão foi a severa admoestação sofrida que, mesmo sendo em sonho, como descreveu Pedro Romero, chegou a envolver dois tapas. O relato termina de forma satisfatória, descrevendo uma boa realização do sacramento e apontando para uma mudança no comportamento do índio. Porém, questiona-se a intenção do indígena a respeito da confissão: diferente dos casos anteriores, o supracitado informa que um pecado fora cometido, mas o pecador precisou de um "sonho" com aparições e uma pancada para só então procurar o confessor. Deste modo, será que estava em seus planos confessar-se? 
GUILHERME GALHEGOS FELIPPE - Confessar sim, mas nem tudo ...

Ou melhor, será que quando foi procurar o padre, o índio tinha a intenção de contar o que presenciou e confessar um pecado cometido?

Estas dúvidas surgem, porque diversos estudiosos da cultura e religião dos índios platinos - tanto históricos como atuais - apontam para uma questão bastante importante a ser analisada aqui: a presença do sobrenatural na vida indígena.

\section{O sobrenatural e duas visões: conflito de crenças}

É conhecida a forte presença da religião e espiritualidade na vida destes índios. Verdadeiras instituições que regravam o cotidiano indígena por meio de rituais e cerimônias que estabeleciam a ordem da aldeia e mantinham viva a tradição e cultura nativa. Segundo Melià (1991, p. 215), "era gente de intensa inclinación y experiencia religiosa, expresada en cantos y danzas, en sueños, visiones y discursos proféticos". Nomeação dos recém-nascidos, renomeação dos guerreiros, antropofagia, exéquias, caça e tantas outras práticas e costumes diários que eram regidos pela religião e todo sistema de crenças que tinham como base a espiritualidade e o constante contato com o sobrenatural. Nimuendaju, por exemplo, afirma que o "Guarani tem muito mais medo dos mortos que da morte" (NIMUENDAJU, 1987, p. 35), isto porque é comum, segundo o autor, a alma do morto ficar

perambulando pelos lugares em que morava e andava em vida, especialmente à noite, e se constitui em grave perigo para os viventes por sua ânsia de se aproximar deles e com eles se comunicar (NIMUENDAJU, 1987, p. 38).

Segundo Cadogan, grupos Guarani chegam a mudar-se quando um adulto morre "por temor al fantasma del muerto" (CADOGAN, 1973, p. 56). Métraux (1979, p. 56), ao tratar dos Tupinambá, também ressalta esta presença contínua de "uma multidão de espíritos que perambulam por toda a parte, sobretudo em matas e sítios obscuros, de aspecto particularmente sinistro", podendo atuar de uma forma "hostil à espécie humana, pois lhes causavam doenças, impediam a vinda das chuvas e provocavam a derrota na guerra". A função das exéquias 
centrava-se justamente em "restabelecer o equilíbrio do sistema de relações sociais por meio da exclusão do membro falecido e da atribuição de um novo status ao morto, na sociedade dos ancestrais" (FERNANDES, 1960, p. 161). Referindo-se aos Guarani históricos, Susnik (1984-85, p. 58) concorda com a atuação hostil que as almas mantinham com os vivos, podendo até mesmo agredi-los.

Os próprios jesuítas citam a presença destes seres sobrenaturais na vida indígena, como faz o padre Montoya ao descrever a crença que os índios tinham sobre a atuação de fantasmas após o enterramento de um morto: "Se, depois de enterrado o defunto, ouvirem-se trovões ao longe, dizem que são uns fantasmas que se sustentam de corpos mortos e que então se juntam para comer aquele" (MCA, 1951, p. 274). Montoya também cita um outro fantasma que:

Anda de casa em casa, do tamanho de um menino, o qual tem figura humana e os cabelos vermelhos e nas mãos uma corda com que afoga. Chamam-no Curupu, que corresponde ao vocábulo de duende, que por outro nome chamam mbae. Este dizem que ajuda em tempo de milho verde, porque é muito amigo dele e de carne e que geralmente aparece quando dormem e afoga-os e, assim, quando morre alguém de repente, dizem que este fantasma o matou (MCA, 1951, p. 273).

Em outro relato pertencente a uma carta anônima também são citados outros dois seres sobrenaturais pertencentes à vida indígena:

Estavam para sair de suas cavernas os Itaquicê e os Ybitiois, que são uns fantasmas fingidos que o povo e o populacho imaginam serem muito horrendos, a quem todos temem muito [...], e matam todos que encontram e os feiticeiros, para confirmar esta falsidade, dão a entender aos índios que os ecos que fazem os montes, devolvendo as palavras e gritos que se dão junto a eles, são as vozes que dão estes fantasmas, repetindo-as de cima para sair atrás dos que as dão. Estes fantasmas monstruosos, dizem os feiticeiros, estão a seu mando e tem-nos ali presos para tirá-los todas vezes que precisam (MCA, 1970, p. 253).

Ao mesmo tempo em que descreve os dois fantasmas, suas atuações e relações com os vivos, o jesuíta afirma que estes seres são 
falsidades criadas pelos xamãs de modo a deixá-los com medo. Tendo a intenção de menosprezar as crenças e superstições indígenas, estes relatos são significativos na medida em que descrevem seres sobrenaturais não pertencentes à mentalidade cristã. $O$ mesmo ocorre com os sonhos que, para os índios, tem uma importância vital em suas atitudes e escolhas. Muito além de imagens e representações que ocorrem durante o sono, o sonho indígena envolve experiências extracorporais da alma:

[...] en el sueño, el cuerpo reposa pero la alma se externa, vaga y de allí la creencia en los sueños porque ellos creen que el alma, al externarse, ve, observa, puede visitar a los parientes, etc. (SUSNIK, 1982 , p. 193).

Desta maneira, o indígena acredita que as "experiências da alma durante os sonhos" tratam-se de "acontecimentos reais capazes de interferir de modo decisivo no rumo da vida das pessoas" (NIMUENDAJU, 1987 , p. 34), como, por exemplo, a "creencia de que 'en el sueño', el alma de un shaman puede 'devorar' el alma temporalmente externada de un viviente" (SUSNIK, 1984-85, p. 119). Enquanto os índios entendiam o sonho como a libertação da alma e uma fonte de saber, os jesuítas acreditavam que eram excessos: "Los guaraníes son gente dada a los sueños y augurios hasta la exageración” (DUVIOLS, 1991, p. 74).

Mesmo afirmando que "todas estas são ignorâncias e abusos dos quais facilmente se livram, se avisados" (MCA, 1951, p. 274), os padres percebem que os índios também têm seus casos extraordinários a serem relatados. Ambas as culturas assemelham-se pela crença em fenômenos que vão além das possibilidades humanas, porém divergem em suas significações. Pode-se dizer que naqueles casos citados anteriormente, envolvendo fenômenos sobrenaturais que, segundo os jesuítas, motivavam os índios a procurarem a confissão, ocorria um conflito de crenças: o indígena contava ao padre que havia sonhado com a alma de algum antepassado, ou que havia visto um fantasma que the deixou assustado e, por sua vez, o padre interpretava tal ocorrido de acordo com as suas crenças e visão de mundo, registrando aquilo que cabia à sua possibilidade do real. Enquanto os índios relatavam 
GUILHERME GALHEGOS FELIPPE - Confessar sim, mas nem tudo ...

experiências sobrenaturais, os jesuítas compreendiam tais situações, ora como intervenções divinas, ora como manifestações diabólicas:

Nesse conjunto de visões e aparições narradas na documentação, tornou-se necessária a subdivisão naquilo que seriam "verdadeiras aparições" e "falsas aparições". O religioso concede 0 caráter de manifestação adequada, na medida em que a narração se refira aos santos intercedendo pelos indígenas aptos à cristandade. Mesmo que ainda não possuam uma boa conduta, a partir da aparição o jesuíta/autor evidencia sua aptidão e predestinação a tornarem-se bons cristãos. Sendo assim, a inadequação do fenômeno é observada nos relatos que exaltam as intervenções demoníacas, conforme representam obstáculos à conversão, evidenciando a manutenção de práticas da cultura Guarani, como poligamia, antropofagia e xamanismo (BERTO, 2006, p. 133).

Aquilo que para o nativo poderia ser uma visão costumeira ganhava uma interpretação própria quando era registrado pelo jesuíta, adquirindo características divinas ou demoníacas. O fato é que havia uma incompatibilidade de crenças, onde os padres procuravam desmistificar as autóctones e implantar as suas ${ }^{5}$.

[...] os evangelizadores queriam que os índios aderissem justamente ao aspecto mais estranho dessa realidade exótica, sem referente visível, sem ancoragem local: o sobrenatural cristão. A empresa era, ao mesmo tempo, fácil e praticamente impossível. Fácil porque, apesar das distâncias consideráveis que os separavam, os dois mundos concordavam em valorizar o surreal a ponto de considerá-lo realidade última, primordial e indiscutível das coisas. Impossível, pois o modo como o concebiam era divergente em todos os sentidos. Os mal-entendidos se multiplicaram (GRUZINSKI, 2003, p. 271-72).

São duas sociedades que apelam para fenômenos e intervenções mágicas e sobrenaturais de forma a explicarem seus cultos e crenças e darem sentido ao irreal, mas que não concordam entre si.

\footnotetext{
${ }^{5}$ Gruzinski, com tom irônico, tratando desta tentativa de substituir as visões nativas pelas cristãs, coloca que "os jesuítas teriam apresentado a índios temporariamente perturbados uma possibilidade de estruturar seus delírios, sob forma de uma série de sintomas restauradores tomados ao cristianismo" (2003, p. 288).
} 
As discordâncias davam-se em praticamente todos os aspectos do contato jesuítico-indígena, principalmente nas questões envolvendo suas crenças, como foi visto. E, ao que parece, não foram apenas os fenômenos sobrenaturais que criaram situações conflituosas no discurso religioso: o conceito de pecado cristão também foi responsável por dificuldades no trabalho reducional. Para os grupos indígenas não existiam atitudes que pudessem transgredir normas estabelecidas por dogmas indiscutíveis, não fazendo parte do seu modo de ser a idéia de responsabilidade moral nem de condutas que resultassem em punições ou recompensas (NIMUENDAJU, 1987, p. 36; SCHADEN, 1974, p. 104; SUSNIK, 1982, p. 193-95).

O pecado como é entendido pelos jesuítas é inexistente para os índios, mas não incompreensível: como se viu no início do capítulo, em diversos casos, são relatados indígenas confessando pecados - às vezes até com aparente exagero, de erros cometidos em épocas pagãs. Os índios pareciam ter clara noção de que, para os padres, o ritual confessional e, por conseguinte, a revelação de condutas que thes parecessem erradas, eram de suma importância para o estabelecimento de uma relação entre os dois. Assim, ao que parece, os nativos não realizavam confissões com a mesma intenção que os jesuítas desejavam, e os pecados não eram assimilados, pelos índios, como equívocos. O que melhor demonstra isto é um outro grupo de relatos confessionais que os padres registram apresentando, consciente ou inconscientemente, falhas nas confissões indígenas e descrevendo-as como tal.

\section{Más confissões}

Frente aos inúmeros casos de índios confessando seus pecados, outros tantos relatos mostram confissões problemáticas, sendo mal praticadas ou indígenas reincidindo nos mesmos pecados. São situações que mostram as dificuldades que os jesuítas enfrentavam em relação à tentativa de ensinar os índios o conceito de pecado, o arrependimento por tê-lo cometido e a necessidade de confessá-lo. Por isso, faziam o "posible para disipar la creencia en que muchos estaban de que en nada 
pecaban, y por consiguiente les era innecesaria la confesión" (DUVIOLS, 1991, p. 78). Em sua carta ânua de 1614, o padre Diogo de Boroa relata dois casos seguidos com praticamente a mesma situação:

Não foi menor misericórdia a que Nosso Senhor usou com outra pessoa que havia encoberto sempre alguns pecados muito vergonhosos e, ainda que se confessasse para morrer, não se confessou bem, mas o Senhor, que a tinha escolhido, adiou muito tempo a doença na qual foi dispondo até que ultimamente, antes de sua morte, se confessasse com muitas lágrimas e sentimento de seus pecados (MCA, 1952, $p$. 18).

Neste primeiro relato, Boroa não identifica quais "pecados muito vergonhosos" o indígena escondeu do padre, mas não lhe restam dúvidas de que até então não havia realizado uma confissão adequada. O agravante está no fato de que, mesmo confessando-se "para morrer", sua disposição não era boa, só melhorando - ironicamente - quando piorou sua saúde, por intervenção divina. Ao final, realizou uma confissão que foi aceita pelo jesuíta, o que não poderia ser de outra forma, já que veio a ser sua última. A mesma estrutura discursiva é usada no segundo relato do padre Boroa:

Moveu Nosso Senhor um índio a que se confessasse bem, o que não havia feito em sua vida, e por sua fraqueza ou instigação do demônio arrependeu-se antes de acabar a confissão. E já estava à morte e assim o padre, com desejo de ajudar aquela alma, voltou à sua casa depois, ainda que estivesse chovendo muito. E perguntando-Ihe se tinha alguma coisa para confessar, disse que sim. Acabou de confessar-se bem e morreu (MCA, 1952, p. 18).

Do mesmo modo, o jesuíta descreve o caso de um índio que realizou uma má confissão, com a diferença de deixar explícito que ele nunca havia realizado bem o sacramento. A situação também ocorre no momento de sua morte, e sua confissão só é satisfatória porque, logo após efetivá-la, morre, tornando-se sua primeira e única confissão bem-realizada. O demônio que o havia impossibilitado de confessar anteriormente não o perturba no leito de morte. 
GUILHERME GALHEGOS FELIPPE - Confessar sim, mas nem tudo ...

O padre Montoya também registra um caso bastante significativo envolvendo más confissões realizadas:

Vencido de vergonha, um índio veio a calar na confissão um pecado de impureza. Adoeceu de imediato, com tais sintomas, que parecia exalar a alma. Prestou-lhe auxílio o próprio confessor, mas, atribuindo o acidente do corpo ao mal da alma, instou com ele que se confessasse de modo bom. Com tal advertência, o índio confessou sua culpa e, à medida que a ia dizendo, melhorava, bem como, depois de recebida a absolvição, achou-se são de todo.

Bem depressa, porém, esqueceu-se e tornou a cair no seu delito. E com isso a Justiça Divina voltou a deitar-lhe a mão com uma doença mortal. Reconhecido, o pobre e fraco do índio novamente recorreu ao remédio comprovado da confissão, com o qual ficou são na alma, não porém no corpo, porque, passados breves dias, terminou a sua vida (RUIZ DE MONTOYA, 1985, p. 225).

Diferente dos casos anteriores, aqui o pecado que levou o indígena ao confessor é revelado. Tendo uma primeira chance de redimir-se e realizar uma boa confissão, o índio omitiu, segundo o autor, o erro que teria cometido. Desta forma, é atacado por uma doença que o leva efetivamente a realizar o sacramento de modo satisfatório, melhorando também sua saúde. Porém, volta a cometer o mesmo pecado, ficando novamente doente. O relato é bastante significativo, na medida em que apresenta não só uma confissão malfeita, mas uma reincidência. Os casos citados anteriormente tinham apenas o problema do sacramento inadequado, sendo resolvido com uma intervenção divina que levava a uma boa confissão e morte. $O$ relato que Montoya registra apresenta um indígena que volta a cometer o mesmo pecado, só não o repetindo outra vez porque morre - assim como os anteriores. Conforme Delumeau (2003, p. 273/ v. 2), "uma má confissão manchava todas as outras confissões posteriores, mesmo completas e sinceras, enquanto o pecado ocultado não fosse confessado", fazendo com que o sacramento só tivesse valor para os padres quando todos os erros cometidos fossem revelados - ou se fosse a derradeira confissão do pecador. A morte parece solucionar todos os problemas surgidos, sejam confissões mal-feitas, sejam reincidências 
do mesmo pecado. Porém, mesmo estes casos terminando de forma edificante, evidenciam o quanto era difícil para os jesuítas implantar a prática confessional entre os nativos, não pela impossibilidade destes de compreender e interiorizar os dogmas cristãos, mas sim pela incompatibilidade de crenças. Como foi colocado anteriormente, os índios que, segundo os padres, realizam más confissões provavelmente não tinham nem a intenção de se confessarem, muito menos deixarem de praticar seus costumes, que eram freqüentemente assimilados a pecados. Observa-se outro caso registrado pelo padre Romero, em sua carta ânua de 1614, também envolvendo uma ocorrência de má confissão:

Havia um índio que muitos anos antes tinha enganado um padre fazendo que o casasse com uma mulher a quem devia ter afeição, e assim calou um impedimento dirimente e ficou muitos anos amancebado com a índia e, ainda que se confessasse, não se atrevia a descobrir sua fraqueza. Enviou-Ihe, Nosso Senhor, uma doença muito grave, mas nem isso aproveitou para se confessar bem, porque ele estava diminuído e muito cativo do demônio, tanto que, depois de receber a extrema-unção e estar próximo à morte, não revelava sua desventura. [...] O padre procurou desenganar-lhe o demônio (cuja presença se sentiu ali quase visivelmente) e sua má vida fazia-Ihe muita força, e assim começou a pôr maldições, tomando os demônios na boca, desejando e ainda dizendo ao padre que se fosse. Mas este não o fez, antes pôs-se com muito afeto em oração, suplicando a Nosso Senhor que livrasse aquela alma das mãos do demônio que a tinha cativa e, oferecendo algumas missas por esta intenção e a majestade de Deus Nosso Senhor, dignou-se de aceitar o sacrifício e sangue de seu filho que lhe oferecia, mudando de repente o coração daquele homem obstinado com tanta abundância de graça que, com lágrimas e extraordinário afeto do coração, começou a pedir, ele mesmo, perdão a Nosso Senhor pelos seus pecados e acabou sua confissão e, compostas todas suas coisas e remediadas, foi Nosso Senhor servido (como se esperava de sua bondade) a levá-lo para si (MCA, 1952, p. 17-8).

A má confissão denunciada pelo jesuíta é justificada pelo fato de o indígena ter escondido durante anos uma união indesejada. Não se 
GUILHERME GALHEGOS FELIPPE - Confessar sim, mas nem tudo ...

casando com a mulher que o padre preferia como sua esposa, o índio passa a ser visto como um pecador que necessita confessar tal erro. Mesmo sendo atingido por uma doença - que foi interpretada como castigo divino em resposta à sua atitude - sua confissão não satisfaz o jesuíta, que passa a orar e prometer missas em troca do arrependimento do indígena. A opção do índio em manter relação com sua manceba torna-se graves pecados de omissão e amancebamento, podendo apenas solucioná-los com sua contrição e o fim da má união. Sua vontade de escolher uma parceira livremente esbarrou nas classificações cristãs do que é certo e errado, resultando-lhe a imagem de pecador. No final, o índio confessa e redime-se, tornando o relato edificante com sua boa morte.

Em sua carta ânua de 1628, o padre Duran descreve um caso de má confissão onde também deixa de registrar certa informação:

Ocultou um índio algumas de suas culpas na confissão;
voltou no dia seguinte ao padre que lhe havia
confessado e disse-lhe: "padre, eu venho confessar-me
de verdade, porque esta noite despertaram-me umas
vozes que me diziam: vai e confessa o que calou,
senão perderás rápido a vida". Fez uma boa confissão
e pouco tempo depois colocou-se a triscar com uma
índia e, no mesmo instante, caiu um raio junto a ele
que o deixou atordoado. Voltou a si cobrando os
sentidos do corpo e também os da alma, sabendo que
era aviso do céu (MCA, 1951, p. 224).

Neste caso, o índio também realiza uma má confissão, segundo o autor, por esconder do confessor algumas "culpas". Descobre-se mais adiante que os erros omitidos são referentes a uniões indesejadas que o índio mantinha. Mesmo após realizar uma boa confissão - movido por vozes que escutou durante a noite -, voltou a cometer o mesmo pecado, o que lhe faz ser atingido por um raio como intervenção divina. Isto deveria motivá-lo a realizar uma nova boa - e derradeira - confissão, mas nada é registrado nesse sentido: Duran apenas confirma que o índio entendeu ser aquele raio um alerta. De acordo com o autor, a última confissão satisfatória que o índio realizou foi a motivada pelas vozes - justamente a anterior a sua reincidência! $O$ relato finaliza sem nova confissão, sem a morte do indígena e sem a certeza de que o 
alerta divino realmente foi eficaz e não o fez voltar a "triscar" com índias.

Apesar dos relatos envolvendo a confissão terem, em sua maioria, um caráter edificante, evidenciam-se grandes dificuldades em administrar o sacramento no meio reducional, um instrumento que deveria manter os índios dentro das boas condutas cristãs, sob a vigia dos padres, e ter a função de reconciliá-los com Deus por terem-no ofendido. Mas pouquíssimos casos registrados dão conta da conduta do indígena após sua confissão, importando mais, para o discurso jesuítico, descrever $o$ ato confessional. Desta forma, os relatos enaltecem o que seria uma boa assimilação do sacramento por parte dos nativos. O fato é que diversas vezes aquilo que os jesuítas interpretam como pecados indígenas são, na realidade, condutas, costumes ou práticas autóctones que não representam, na cultura nativa, nenhum erro ou falha comportamental. É a visão de mundo dos padres que entende as atitudes indígenas como algo errado, passível de punição. Por isso, quando os índios escolhem com quem querem manter um relacionamento conjugal, partindo de suas prerrogativas e regras matrimoniais, os jesuítas observam uniões inadequadas e pecaminosas. É um conflito de crenças gerado em uma realidade nova, tanto para os padres como para os índios, onde cada um observa, interpreta e age de acordo com seu modo de ser - os primeiros classificando todas as atitudes nativas como falhas morais, e os segundos tentando adaptar-se à situação, relacionando-se com os primeiros, sem perder de vista sua cultura e tradição.

\section{Referências bibliográficas}

BERTO, Carla. Milagres constantes e inconstantes: variações no discurso jesuítico (1610-1640). 2006. 188 f. Dissertação (Mestrado em História) - PUCRS, [2006].

CADOGAN, León. Cadogan según Cadogan. Suplemento Antropológico, Assunção, v. 8, n. 1-2, p. 53-64, 1973. 
DELUMEAU, Jean. O pecado e o medo: a culpabilização no Ocidente (séculos 13-18), São Paulo: Edusc, 2003. 2v.

FELIPPE, Guilherme G. Variações discursivas sobre os registros sacramentais: batismo, confissão e matrimônio nas reduções jesuíticas (1609-1640). 2007. 137 f. Dissertação (Mestrado em História) - PUCRS, [2007].

FERNANDES, Florestan. A organização social dos Tupinambá. São Paulo: Instituto Progresso Editorial, 1960.

GRUZINSKI, Serge. A Colonização do Imaginário: sociedades indígenas e ocidentalização no México espanhol (Séculos XVI - XVIII). São Paulo: Companhia das Letras, 2003.

MELIÀ, Bartomeu. Misión por reducción. Suplemento Antropológico, Assunção, v. XXVI, n. 1, p. 213-228. 1991.

MÉTRAUX, Alfred. A religião dos Tupinambás e suas relações com a das demais tribos Tupi-Guaranis. São Paulo: Ed. Nacional/EDUSP, 1979.

NIMUENDAJU, Curt. As lendas da criação e destruição do mundo como fundamentos da religião dos Apapocúva-Guarani. São Paulo: Editora Hucitec, 1987.

SCHADEN, Egon. Aspectos fundamentais da cultura Guarani. São Paulo: EDUSP, 1974.

SUSNIK, Branislava. El rol de los indígenas en la formación y en la vivencia del Paraguay. Asunción: Instituto Paraguayo de Estudios Nacionales, 1982. Tomo I.

Los aborígenes del Paraguay VI: aproximación a las creencias de los indígenas. Asunción: Museo Etnográfico "Andrés Barbero", 1984-85.

VAINFAS, Ronaldo. Trópico dos pecados: moral, sexualidade e Inquisição no Brasil. Rio de Janeiro: Nova Fronteira, 1997.

\section{Referências documentais}

Fontes manuscritas

Manuscritos da Coleção de Angelis (MCA-CPH) ${ }^{6}$

Cx. 14, doc. 12 1612. Relación de un viaje á las misiones del Guayra. ( $\left.\mathrm{n}^{\circ} 258\right)$.

\footnotetext{
${ }^{6}$ As referências dos documentos manuscritos estão de acordo com a localização dos microfilmes no Centro de Pesquisas Históricas do Programa de Pós-Graduação em História da PUCRS. Tais cópias microfilmadas foram adquiridas através de um projeto financiado pelo $\mathrm{CNPq}$, cujos originais pertencem à Biblioteca Nacional do RJ.
} 
GUILHERME GALHEGOS FELIPPE - Confessar sim, mas nem tudo ...

Cx. 28, doc. 08 1613. Anua de la reducción de San Ignacio del Paraná con la descripción de las tierras del Iguai. ( $\left.{ }^{\circ} 856\right)$.

Cx. 28, doc. 11 1615. Carta annua de las misiones del Paraná. (n 859).

Cx. 28, doc. 15 1619. Carta annua de la reducción de $N^{\text {tra }}{ }^{\text {ra }}{ }^{\text {de }}$ la Encarnación de Itapuã. (n 863).

Cx. 29, doc. 5 1643. Carta anua de la reducción de Santa Ana. (n 887).

Cx. 29, doc. $6 \quad$ 1642. Carta anua de la reducción de Santa Maria del Uruguay. $\left(\mathrm{n}^{\circ}\right.$ 888).

Cx. 29, doc. 7 1642. Carta anua de la reducción de San Miguel del Uruguay. $\left(\mathrm{n}^{\circ}\right.$ 889).

Fontes impressas

DOCUMENTOS PARA LA HISTORIA ARGENTINA (DHA). Cartas anuas de la Provincia del Paraguay, Chile y Tucumán, de la Compañía de Jesús (1609-1614). Buenos Aires: Talleres S. A. Casa Jacobo Peuser, 1927. Tomo XIX,

DUVIOLS, Jean-Paul; SAGUIER, Rubén Bareiro (Org.). Tentación de la Utopia. Barcelona: Tusquets, 1991.

MANUSCRITOS DA COLEÇÃO DE ANGELIS (MCA). Jesuítas e Bandeirantes no Guairá (1549-1640), Rio de Janeiro: Biblioteca Nacional, 1951. v. I.

. Jesuítas e Bandeirantes no Itatim (1596-1760). Rio de Janeiro: Biblioteca Nacional, 1952. v. II.

. Jesuítas e Bandeirantes no Tape (1615-1641). Rio de Janeiro: Biblioteca Nacional, 1969. v. III.

. Jesuítas e Bandeirantes no Uruguai (1611-1758). Rio de Janeiro: Biblioteca Nacional, 1970. v. IV.

RUIZ DE MONTOYA, Pe. Antonio. Conquista espiritual feita pelos religiosos da Companhia de Jesus nas Províncias do Paraguai, Paraná, Uruguai e Tape [1639]. Porto Alegre: Martins Livreiro, 1985. 